\title{
Novel, nonresectional mitral valve repair-another tool in the mitral surgeon's armamentarium
}

\author{
Malini Daniel, MD, and Pavan Atluri, MD
}

\footnotetext{
From the Division of Cardiovascular Surgery, Department of Surgery, University of Pennsylvania School of Medicine, Philadelphia, Pa.

Disclosures: Authors have nothing to disclose with regard to commercial support.

Received for publication June 6, 2017; accepted for publication June 12, 2017; available ahead of print July 18, 2017.

Address for reprints: Pavan Atluri, MD, Assistant Professor of Surgery, Director, Minimally Invasive and Robotic Cardiac Surgery, Director, Heart Transplant and Mechanical Circulatory Support, University of Pennsylvania, 6 Silverstein Pavilion, 3400 Spruce St, Philadelphia, PA 19104 (E-mail: Pavan.atluri@uphs.upenn.edu).

J Thorac Cardiovasc Surg 2017;154:1250-1

$0022-5223 / \$ 36.00$

Copyright $(2017$ by The American Association for Thoracic Surgery

http://dx.doi.org/10.1016/j.jtcvs.2017.06.022
}

As the demand for minimally invasive mitral valve surgery expands with reproducible noninferiority compared with open approaches ${ }^{1,2}$ combined with reduced hospital stay and postoperative pain, ${ }^{3}$ repair techniques that improve the ease and rapidity of minimally invasive approaches increasingly are desirable. MacArthur and colleagues ${ }^{4}$ previously argued that nonresectional techniques for leaflet prolapse may improve accessibility of minimally invasive repair by improving technical ease and decreasing bypass time compared with resectional techniques. ${ }^{5}$ Nonresectional techniques have the added advantage of reversibility and intraoperative re-repair, which is especially important, given the move toward operating on still-asymptomatic patients with severe mitral regurgitation (MR) for whom a near-100\% success of repair should be sought. ${ }^{4,6-9}$ In this issue of the Journal, Agnino and colleagues ${ }^{5}$ describe a novel nonresectional technique for leaflet prolapse involving a free-margin running suture (FMRS). The authors assert that this technique provides for expeditious leaflet repair and maintains adequate coaptation length with the theoretical advantage of decreased fibrosis at the resection site which, if proven true, could improve duration of repair. $^{10}$

In their series $(\mathrm{N}=15)$, the authors used FMRS to achieve adequate repair with only one case of more-than-mild MR. They imply that FMRS carries a lower chance of leaflet fibrosis compared with resectional techniques, leading to lower chance of recurrent MR, and they do demonstrate durability at their 6-month time point. Longer-term durability remains in question, and the premise that lack of resection produces a lower rate of leaflet fibrosis compared with nonresectional techniques still involving leaflet sutures is feasible, although not proven. Considering David's ${ }^{10}$ excellent series demonstrating freedom from recurrent moderate $(69.2 \%)$ or severe $(90.7 \%)$ MR at 20 years, the leaflet fibrosis theory may lack consequence.

The authors propose selection criteria for the appropriate application of FMRS and suggest FMRS may be more useful

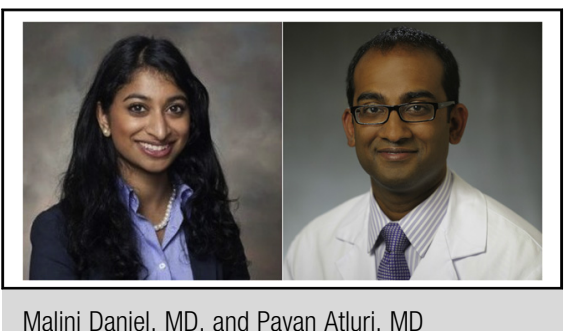

Malini Daniel, MD, and Pavan Atluri, MD

\section{Central Message}

Nonresectional techniques including freemargin running suture for mitral valve repair may improve technical feasibility for minimally invasive approaches, but further analysis of outcomes is warranted.

See Article page 1247. than existing nonresectional techniques for more extensive prolapses with more than one diseased segment, ${ }^{5}$ but they do not demonstrate this. Given their immediate results and 6-month follow-up, the suggestion of noninferiority compared with existing nonresectional and resectional techniques is conceivable in the short term, but more long-term data ultimately are necessary to help assess the utility of FMRS. Moreover, although Woo and colleagues ${ }^{4,8}$ previously demonstrated that their nonresectional techniques decrease bypass time compared with quadrangular resection, Agnino and colleagues, while citing their average bypass and crossclamp time, do not compare this with their institution's cardiopulmonary bypass time for resectional techniques. Not knowing the amount of bypass time saved compromises our understanding of the place of FMRS among repair techniques.

FMRS and other nonresectional techniques, in preserving all leaflet tissue, virtually ensure adequate coaptation length. However, this comes at the risk of retention of excessive posterior leaflet height, which could shift coaptation surface anteriorly and predispose patients to SAM. Although the authors suggest avoiding undersizing the ring to limit risk of SAM, a larger series with more granular assessment using known echo-based SAM risk factors is warranted.

Ultimately, Agnino and colleagues ${ }^{5}$ describe an interesting tool to add a surgeon's armamentarium for mitral valve repair, especially in minimally invasive approaches. With more data regarding comparative bypass time and 
demonstration of longer-term durability of repair, it is conceivable that this technique could be increasingly useful.

\section{References}

1. Suri RM, Schaff HV, Meyer SR, Hargrove WC III. Thoracoscopic versus open mitral valve repair: a propensity score analysis of early outcomes. Ann Thoracic Surg. 2009;88:1185-90.

2. Svensson LG, Atik FA, Cosgrove DM, Blackstone EH, Rajeswaran J, Krisnaswamy G, et al. Minimally invasive versus conventional mitral valve surgery: a propensity-matched comparison. J Thorac Cardiovasc Surg. 2010;139:926-32.

3. Galloway AC, Schwartz CF, Ribakove GH, Crooke GA, Gogoladze G, Ursomanno P, et al. A decade of minimally invasive mitral repair: long-term outcomes. Ann Thorac Surg. 2009;88:1180-4.

4. MacArthur JW Jr, Cohen JE, Goldstone AB, Fairman AS, Edwards BB, Hornick MA, et al. Nonresectional single-suture leaflet remodeling for degenerative mitral regurgitation facilitates minimally invasive mitral valve repair. Ann Thorac Surg. 2013;96:1603-6.
5. Agnino A, Parrinello M, Panisi P, Anselmi A. Novel nonresectional posterior leaflet remodeling approach for minimally invasive mitral repair. J Thorac Cardiovasc Surg. 2017;154:1247-9.

6. Stevens LM, Rodriguez E, Lehr EJ, Kindell LC, Nifong LW, Ferguson TB, et al. Impact of timing and surgical approach on outcomes after mitral valve regurgitation operations. Ann Thorac Surg. 2012;93: 1462-8.

7. Enriquez-Sarano M, Avierinos JF, Messika-Zeitoun D, Detaint D, Capps M Nkomo V, et al. Quantitative determinants of the outcome of asymptomatic mitra regurgitation. $N$ Engl J Med. 2005;352:875-83.

8. Woo YJ, MacArthur JW Jr. Simplified nonresectional leaflet remodeling 127 mitral valve repair for degenerative mitral regurgitation. J Thorac Cardiovasc Surg. 2012;143:749-53.

9. Gillinov AM, Mihaljevic T, Blackstone EH, George K, Svensson LG, Nowicki ER, et al. Should patients with severe degenerative mitral regurgitation delay surgery until symptoms develop? Ann Thorac Surg. 2010;90:481-8.

10. David TE, Armstrong S, McCrindle BW, Manlhiot C. Late outcomes of mitral valve repair for mitral regurgitation due to degenerative disease. Circulation. 2013;127:1485-92. 